Phosphorus Research Bulletin Vol. 12 (2001), 19-24

\title{
HYDROTHERMAL SYNTHESIS OF CALCIUM PHOSPHATES SPHERICAL PARTICLES
}

\author{
Koji IOKU, Akira OSHITA, Hirotaka FUJIMORI, Yoshinori NAKAMURA*, \\ Keiko FUJIWARA*, Seishi GOTO and Masahiro YOSHIMURA** \\ Division of Applied Medical Engineering Science, Graduate School of Medicine, \\ Yamaguchi University, 2-16-1 Tokiwadai, Ube, Yamaguchi 755-8611, Japan \\ * Department of Advanced Materials Science and Engineering, Faculty of Engineering, \\ Yamaguchi University, 2-16-1 Tokiwadai, Ube, Yamaguchi 755-8611, Japan \\ **Materials and Structures Laboratory, Tokyo Institute of Technology, 4259 Nagatsuta, \\ Midori, Yokohama, Kanagawa 226-8503, Japan
}

\begin{abstract}
Spherical particles of hydroxyapataite with $\beta$-tricalcium phosphate were prepared from spherical calcite particles by hydrothermal method. The spherical calcite particles of about $2.5 \mathrm{~mm}$ in size as the starting materials were formed through the process which transformed hard water to soft water. The spherical calcite particles were treated hydrothermally in the solution of diammonium hydrogen phosphate under the saturated vapor pressure. In the case of hydrothermal condition at $270{ }^{\circ} \mathrm{C}$ for $96 \mathrm{~h}$ using $2.0 \mathrm{~mol} \cdot \mathrm{dm}^{-3}$ diammonium hydrogen phosphate solution, hydroxyapatite was formed with a small amount of $\beta$-tricalcium phosphate. From the SEM observation for the sample treated hydrothermally at $270{ }^{\circ} \mathrm{C}$ for $96 \mathrm{~h}$ with a solution of $\mathrm{pH} 10$, needle-like particles of about $2 \mu \mathrm{m}$ in length was observed on the fractured surface.
\end{abstract}

\section{INTRODUCTION}

Hydroxyapatite $\left(\mathrm{Ca}_{10}\left(\mathrm{PO}_{4}\right)_{6}(\mathrm{OH})_{2}: \mathrm{HA}\right)$ and $\beta$-tricalcium phosphate $\left(\beta-\mathrm{Ca}_{3}\left(\mathrm{PO}_{4}\right)_{2}\right.$ : $\beta$-TCP) are promising implant materials as a bone substitute owing to its excellent osteoconductive properties $^{1,2}$. In addition, HA can be used as ion exchangers, separators and sensors. The spherical particles of calcium phosphates will be useful in many fields such as packing media of chromatography for separating amino acid, protein etc $^{3-5}$. Calcite $\left(\mathrm{CaCO}_{3}\right)$ spherical particles are formed in the apparatus during the processing of hard water to soft one. They are disposed as waste without any applications. Hydrothermal processing has been shown to be suitable for preparation of HA with the controlled composition and shape ${ }^{6,7}$. The present study deals with the hydrothermal

Received May 25, 2001; Accepted July 23, 2001 
preparation of spherical particles of calcium phosphates from spherical calcite particles using the diammonium hydrogen phosphate $\left(\left(\mathrm{NH}_{4}\right)_{2} \mathrm{HPO}_{4}\right)$ solution.

\section{EXPERIMENTAL}

Spherical calcite particles of about $0.25 \mathrm{~g}$ were soaked in $2.0 \mathrm{~mol} \cdot \mathrm{dm}^{-3}$ $\left(\mathrm{NH}_{4}\right)_{2} \mathrm{HPO}_{4}$ aqueous solution of $13.5 \mathrm{~cm}^{3}$, and then they were treated hydrothermally using a mini-autoclave at temperatures from $150{ }^{\circ} \mathrm{C}$ to $270{ }^{\circ} \mathrm{C}$ for periods up to $96 \mathrm{~h}$ under saturated vapor pressure. The $\mathrm{pH}$ value of the solutions was controlled from 8 to 10 at room temperature by addition of aqueous ammonia $\left(\mathrm{NH}_{3}\right.$ aq. $)$. Pure calcite powders (Wako pure chemical, reagent grade, Japan) were treated hydrothermally under the same conditions as that of the spherical calcite in order to investigate the influence of impurities in spherical calcite particles on the phase formation during the hydrothermal reaction.

Chemical compositions of samples and the treatment solutions after hydrothermal treatment were analyzed by atomic absorption spectrometry (AAS; Hitachi Z-5310, Japan). The produced phases were identified by powder X-ray diffractometry with graphite-monochromatized $\mathrm{CuK} \alpha$ radiation (XRD; MAC Science $\mathrm{MXP}^{3}$, Japan). The integrated intensity of XRD lines of HA $\left(2 \theta=31.8^{\circ}\right)$ and $\beta$-TCP $\left(2 \theta=31.0^{\circ}\right)$ was compared with the calibration curve ${ }^{8)}$ in order to estimate the quantities of HA and $\beta$ TCP. Fourier transform infrared spectra (FT-IR; Perkin Elmer Spectrum 2000, USA) were obtained from powdered samples mixed with spectroscopic grade $\mathrm{KBr}$. The morphology of the samples was observed by scanning electron microscopy (SEM; JEOL JSM25S, Japan).

\section{RESULTS AND DISCUSSION}

\section{Starting Material}

No phases other than calcite ${ }^{9)}$ were detected by XRD and FT-IR. Chemical compositions of the starting material analyzed by AAS were as follows; $\mathrm{CaO} 95.5$, 
$\mathrm{MgO}$ 2.7, $\mathrm{SrO} 0.4, \mathrm{MnO} 0.0, \mathrm{Na}_{2} \mathrm{O}$ 1.4, $\mathrm{K}_{2} \mathrm{O} 0.0 \mathrm{~mol} \%$. The major impurities were $\mathrm{Mg}$, $\mathrm{Na}$ and Sr. The spherical calcite particles had a porosity of about $20 \%$. Fractured surface of the particle showed the shape of polyhedron which is a part of calcite crystal shape.

\section{Samples after Hydrothermal Treatment}

The shape of samples was not changed after hydrothermal treatment (FIGURE 1).

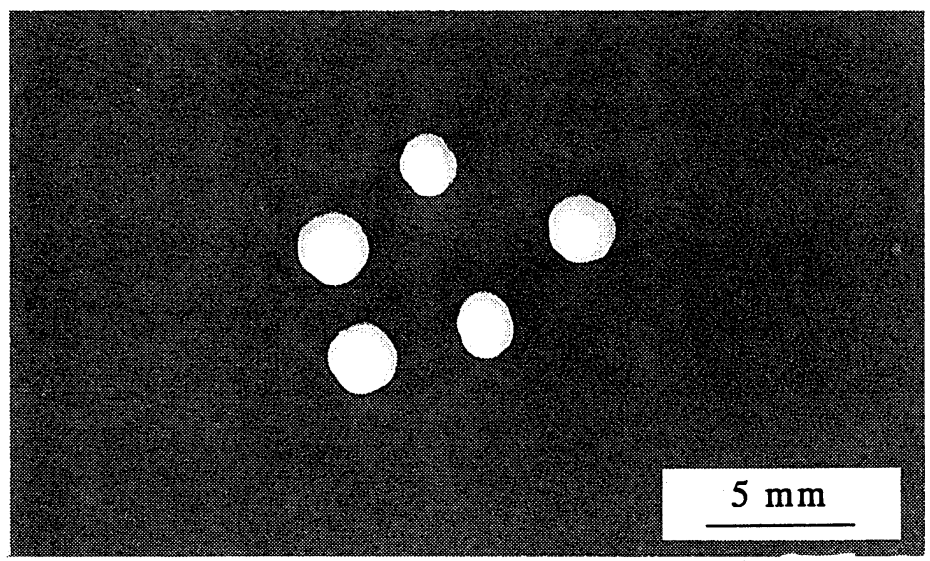

FIGURE 1 Spherical particles of calcium phosphates prepared by hydrothermal treatment at $270{ }^{\circ} \mathrm{C}$ for $96 \mathrm{~h}$ with a $2.0 \mathrm{~mol} \cdot \mathrm{dm}^{-3}\left(\mathrm{NH}_{4}\right)_{2} \mathrm{HPO}_{4}$ aqueous solution. The solution was $\mathrm{pH}$-controlled with an aqueous $\mathrm{NH}_{3}(\mathrm{pH}=10)$.

The formed crystal phases due to hydrothermal reaction were calcium phosphates of $\mathrm{HA}^{10)}$ and $\beta-\mathrm{TCP}^{11)}$. Patterns of XRD for the powdered products prepared hydrothermally at $270{ }^{\circ} \mathrm{C}$ for $24 \mathrm{~h}$ without $\mathrm{pH}$ control showed that unreacted calcite remained in the hydrothermally treated samples. The effect of the period of hydrothermal treatment with $\mathrm{pH}$ control by addition of aqueous $\mathrm{NH}_{3}$ is shown in FIGURE 2. Unreacted calcite was not recognized in the sample prepared at $270{ }^{\circ} \mathrm{C}$ for $96 \mathrm{~h}$ with high $\mathrm{pH}$ solution ( $\mathrm{pH} 10$ at room temperature). According to FT-IR measurement of the samples treated hydrothermally at $270{ }^{\circ} \mathrm{C}$, the peaks around $650 \mathrm{~cm}^{-}$ ${ }^{1}$ and $3570 \mathrm{~cm}^{-1}$ due to $\mathrm{OH}^{-}$group are seen with a small peak around $1420 \mathrm{~cm}^{-1}$ due to $\mathrm{CO}_{3}{ }^{2-}$ group. Therefore a part of $\mathrm{OH}^{-}$in $\mathrm{HA}$ must have been exchanged by $\mathrm{CO}_{3}{ }^{2-}$, and thus the formed HA was carbonated-hydroxyapatite. From SEM observation of samples treated hydrothermally at $270{ }^{\circ} \mathrm{C}$ for $96 \mathrm{~h}$ with $\mathrm{pH} 10$ solution, needle-like particles of about $2 \mu \mathrm{m}$ in length were observed on the fractured surface (FIGURE 3 ). 


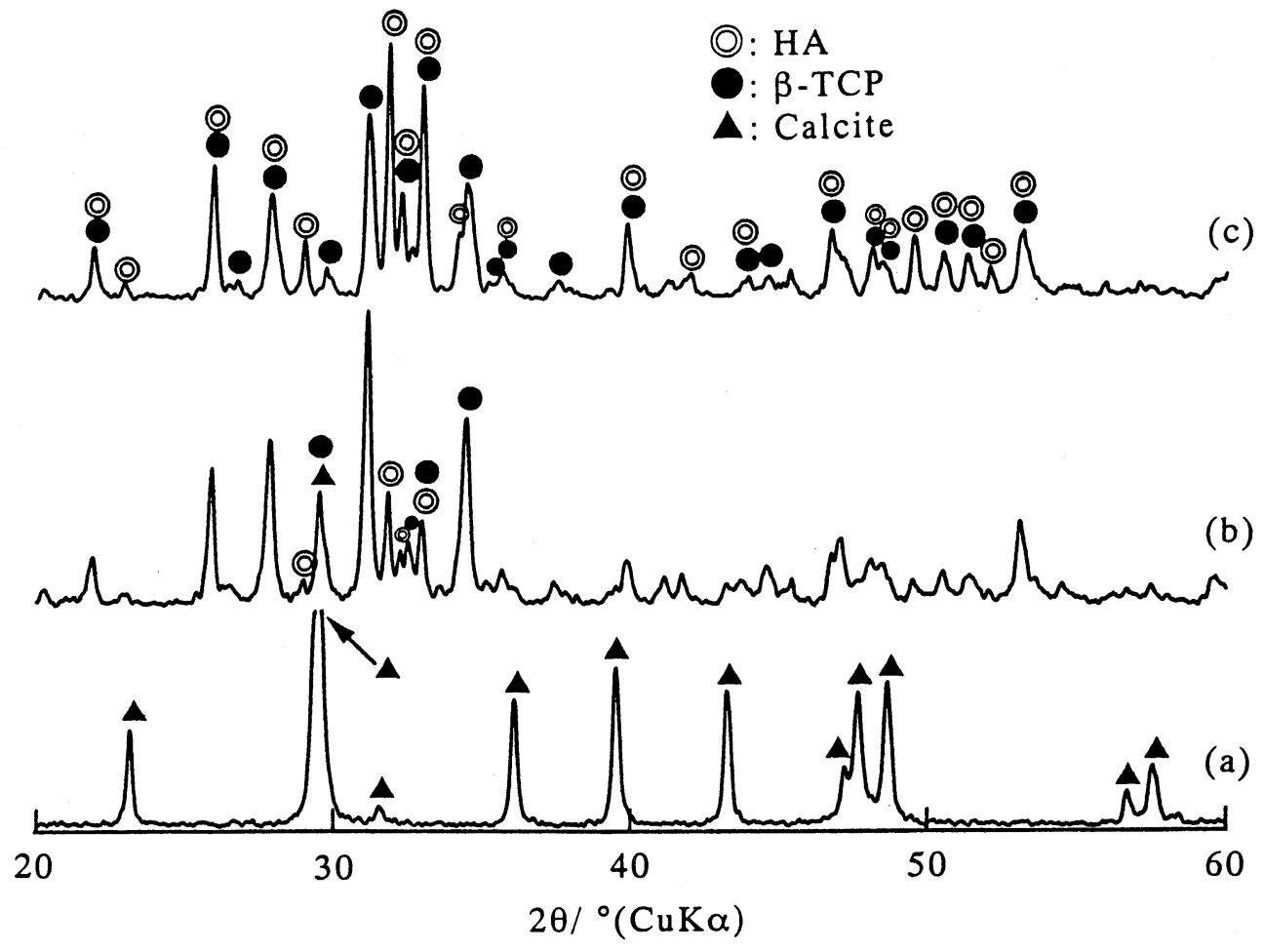

FIGURE 2 Patterns of XRD for the samples treated hydrothermally at $270^{\circ} \mathrm{C}$ in $2.0 \mathrm{~mol} \cdot \mathrm{dm}^{-3}\left(\mathrm{NH}_{4}\right)_{2} \mathrm{HPO}_{4}$ aqueous solution with $\mathrm{pH}$ control by aqueous $\mathrm{NH}_{3}(\mathrm{pH}=10)$; (a) starting calcite, (b) for $24 \mathrm{~h}$, (c) for $96 \mathrm{~h}$.

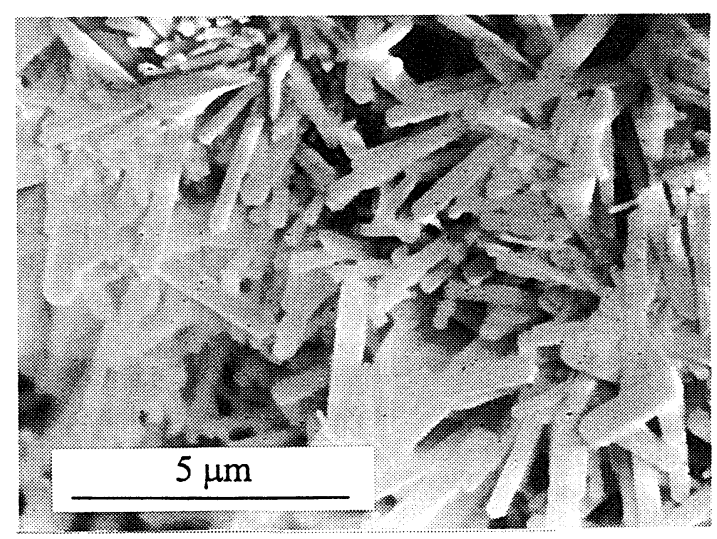

FIGURE 3 SEM observation for the sample treated hydrothermally at $270{ }^{\circ} \mathrm{C}$ for $96 \mathrm{~h}$ in $2.0 \mathrm{~mol} \cdot \mathrm{dm}^{-3}\left(\mathrm{NH}_{4}\right)_{2} \mathrm{HPO}_{4}$ aqueous solution with $\mathrm{pH}$ control by aqueous $\mathrm{NH}_{3}(\mathrm{pH}=10)$. 

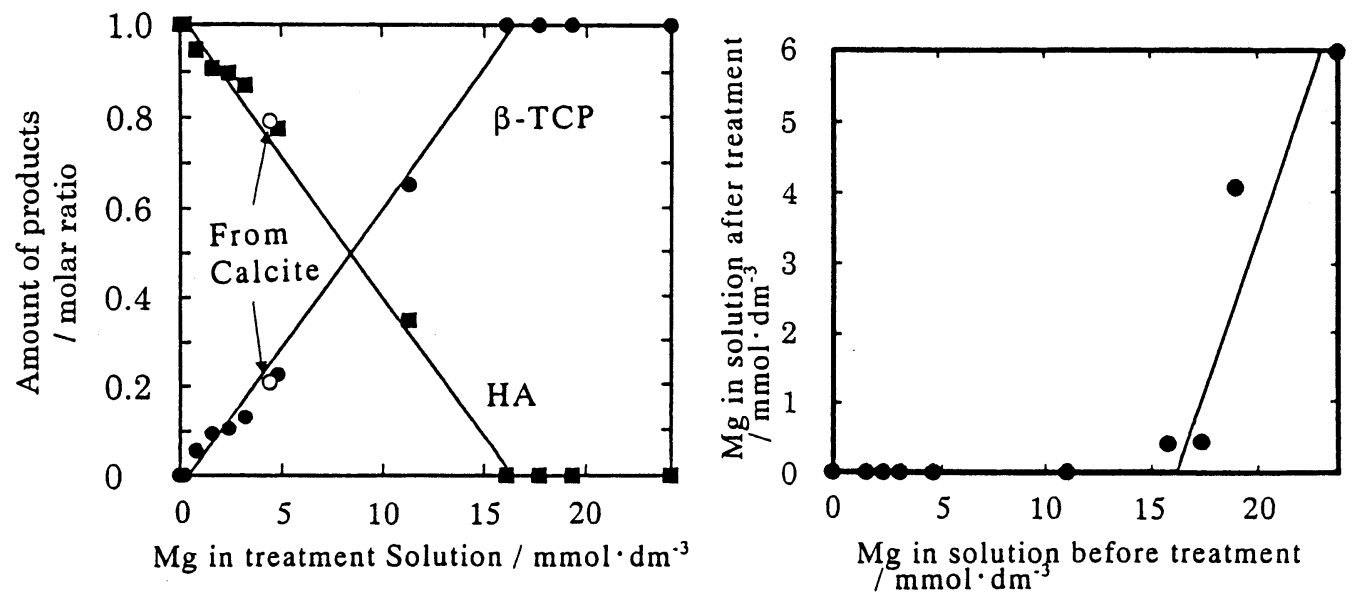

FIGURE 4 Relationship between (a) magnesium concentration of treatment solution and formed phase, (b) magnesium concentration in the solution before and after treatment.

\section{Effect of $\mathrm{Mg}^{2+}$ on Phase Formation}

In the past report, HA was formed from aragonite containing a small amount of $\mathrm{Mg}^{2+}$, and $\beta$-TCP was formed from calcite containing larger amount of $\mathrm{Mg}^{2+}{ }^{12}$. In addition, $\mathrm{Mg}^{2+}$ containing whitlockite was formed from the reaction system containing 3 mol\% $\mathrm{Mg}^{2+}$ in the reaction solution ${ }^{13)}$. Therefore, it was considered that formed phases of calcium phosphates depended on the existence of $\mathrm{Mg}^{2+}$. In order to investigate the influence of $\mathrm{Mg}^{2+}$ on the phase formation, the reagent grade calcite without $\mathrm{Mg}^{2+}$ was treated hydrothermally at $270^{\circ} \mathrm{C}$ for $48 \mathrm{~h}$ with $2.0 \mathrm{~mol} \cdot \mathrm{dm}^{-3}\left(\mathrm{NH}_{4}\right)_{2} \mathrm{HPO}_{4}$ solution or the solution containing $\mathrm{Mg}^{2+}$. From XRD, only $\mathrm{HA}$ was formed from the pure calcite by hydrothermal treatment in the solution without $\mathrm{Mg}^{2+}$. In the contrast, $\beta$-TCP was formed by hydrothermal treatment with the solution containing $\mathrm{Mg}^{2+}$. The amount of $\beta-\mathrm{TCP}$ increased linearly with the increasing concentration of $\mathrm{Mg}^{2+}$ (FIGURE 4(a)). When the $\mathrm{Mg}^{2+}$ concentration of the solutions exceeded $1.6 \times 10^{-2} \mathrm{~mol} \cdot \mathrm{dm}^{-3}$, only the formation of $\beta$-TCP was observed without HA. FIGURE 4(b) shows the concentration of $\mathrm{Mg}^{2+}$ in the solution of $2.0 \mathrm{~mol} \cdot \mathrm{dm}^{-3}\left(\mathrm{NH}_{4}\right)_{2} \mathrm{HPO}_{4}$ before and after the hydrothermal treatment. When the concentration of $\mathrm{Mg}^{2+}$ before the treatment was below $1.6 \times 10^{-2} \mathrm{~mol} \cdot \mathrm{dm}^{-3}$, $\mathrm{Mg}^{2+}$ was not detected in the solutions after hydrothermal treatment. Therefore, it can be 
elucidated that $\mathrm{Mg}^{2+}$ existed in HA and $\beta$-TCP crystal structures. The result of phase formation for hydrothermally treated spherical calcite at $270^{\circ} \mathrm{C}$ for $96 \mathrm{~h}$ agreed with the results indicated in FIGURE 4(a). The amount of maximum $\mathrm{Mg}^{2+}$ in $\beta$-TCP was 10 mol\%, which was estimated from the sample of only $\beta$-TCP without HA formed hydrothermally in $1.6 \times 10^{-2} \mathrm{~mol} \cdot \mathrm{dm}^{-3}\left(\mathrm{NH}_{4}\right)_{2} \mathrm{HPO}_{4}$ aqueous solution.

\section{SUMMARY}

Spherical particles of calcium phosphates were prepared hydrothermally from spherical calcite particles. Carbonated hydroxyapatite with $\beta$-tricalcium phosphate was synthesized by using diammonium hydrogen phosphate solution with addition of aqueous ammonia. The formation of $\beta$-tricalcium phosphate was caused by $\mathrm{Mg}^{2+}$ in the spherical calcite.

\section{ACKNOWLEDGEMENT}

The present work has been supported by cooperative programs in the Material and Structures Laboratory of Tokyo Institute of Technology, and supported partly by RSP project of Yamaguchi Prefecture, Japan. The authors also wish to thank Ube Materials Co. Ltd., Japan for the sample supply.

\section{REFERENCES}

1. H. Aoki, Medical Applications of Hydroxyapatite, Ishiyaku Euro America Inc., Tokyo, St. Louis (1994).

2. K. Ioku, J. Soc. Inorg. Mater. Japan, 8, 153-159 (2001).

3. T. Okuyama, T. Ogawa, and M. Ebihara, J. Soc. Inorg. Mater. Japan (Gypsum \& Lime), [210], 65-73 (1987).

4. T. Kawasaki, Ceramics Japan, 20, [3], 195-202 (1985).

5. K. Nakamura, Ceramics Japan, 23, [11], 1065-1068 (1988).

6. K. Ioku, M. Yoshimura and S. Somiya, Nippon Kagaku Kaishi (J. Chem. Soc. Japan), [9], 1565-1570 (1988).

7. M. Yoshimura and H. Suda, "Hydrothermal Processing of Hydroxyapatite: Past, Present, and Future", in Hydroxyapatite and Related Materials, edited by P. Brown, B. Constantz, CRC Press, Boca Raton, Ann Arbor, London, Tokyo (1994).

8. K. Ioku, T. Murakami, Y. Ikuma and M. Yoshimura, J. Ceram. Soc. Japan, 100, [8], 1015-1019 (1992).

9. Powder Diffraction File, Card \#5-586

10. Powder Diffraction File, Card\#9-432

11. Powder Diffraction File, Card \#9-169

12. D. M. Roy and S. K. Linnehan, Nature, 247, 220-222 (1974).

13. K. Hashimoto, Y. Toda, T. Arakawa, T. Saitoh, T. Kanazawa and S. Udagawa, J. Soc. Inorg. Mater. Japan (Muki-materiaru), 2, 171-180 (1995). 